\title{
DETERMINAN FEE AUDIT : STUDI KASUS PADA ENTITAS MIKRO, KECIL DAN MENENGAH DI PROVINSI BANTEN
}

\author{
Roza Mulyadi (1) \\ Universitas Sultan Ageng Tirtayasa Universitas \\ roza_mulyadi2102@yahoo.com \\ Chandra Prasadhita ${ }^{(2)}$ \\ Universitas Sultan Ageng Tirtayasa \\ chandraprasadhita8@gmail.com
}

\begin{abstract}
Audit fees are important in the process of auditing a financial statement. The main objective of this research is to empirically investigate the determinants that influence audit fees for EMKM sector companies such as company size, profitability, company risk, complexity, type of industry and the status of the Public Accounting Firm. Samples taken from this study were 34 EMKM companies in Banten Province. The data source used is primary data. Primary data obtained by distributing questionnaires to respondents. The results of this study indicate that company size and company risk have a significant relationship to audit fees, while company profitability, complexity, type of industry, and KAP status do not have a significant relationship.
\end{abstract}

Keywords: Company Size, Priability, Company Risk, Complexity, Industry Type, KAP Status, Audit Fee 


\section{PENDAHULUAN}

Dalam Era Globalisasi, bidang akuntansi merupakan bidang yang paling banyak memegang peranan dalam pengambilan keputusan oleh perusahaan terutama laporan keuangan (Arsyad \& Ghozali, I, 2017), oleh karena itu untuk meningkatkan kredibilitas dan kualitas laporan keuangan diperlukan audit eksternal (Beasley \& Salterio, 2001, Hallak \& Silva, 2012,). Laporan keuangan yang diaudit dapat mengurangi asismetri informasi dan konflik antara manajer dengan stakeholder (Bealty 1989; Willenborg, 1999). Namun demikian kualitas audit dapat diukur dengan jumlah fee audit yang dibayarkan oleh perusahaan untuk auditor eksternal (Hallak \& Silva, 2012). Peningkatan kebutuhan atas jasa akuntan publik didasari oleh masalah keagenan. Masalah keagenan dapat terjadi karena adanya asymmetric information antara prinsipal dan agen. Asymmetric information terjadi ketika salah satu pihak memiliki informasi yang tidak dimiliki oleh pihak lainnya (Chandra, 2015). Akuntan publik memiliki peranan penting untuk meningkatkan transparansi dan mutu informasi dalam bidang keuangan.

Penelitian ini dimotivasi oleh kepentingan atas pasar audit (Gerakos \& Syverson, 2013) dimana Pasar audit berperan penting dalam rangka menciptakan transparasi dan meningkatkan pasar modal (Watts \& Zimmerman, 1993; Ball, 2001; Hitam, 2001, selain itu di Indonesia semua perusahaan wajib untuk diaudit (Undang undang No. 40 Tahun 2007; SPAP, 2011). Berdasarkan Data Pusat Pembinaan Profesi Keuangan (P2PK) Kementerian Keuangan Republik Indonesia (24 Mei 2018) Jumlah Kantor Akuntan Publik di Indonesia sebanyak 444 kantor, dimana jumlah ini tidak sebanding dengan jumlah EMKM yang ada.

Oleh karena itu tujuan utama penelitian ini adalah untuk menginvestigasi secara empiris faktorfaktor penentu yang mempengaruhi fee audit untuk perusahaan sektor EMKM seperti hal nya ukuran perusahaan, profitabilitas, resiko perusahaan, kompleksitas, jenis industri dan status Kantor Akuntan Publik. Penelitian seperti ini penting karena beberapa alasan : Pertama, membantu dan memperluas literatur yang ada, karena keterbatasan faktor-faktor penentu fee audit di Indonesia, apalagi standar fee audit di Indonesia berdasarkan tarif jam kerja. Kedua, Mengkaji sejauhmana penerapan PSAK ETAP di Indonesia untuk Perusahaan Sektor EMKM. Ketiga, membantu Organisasi Akuntan Publik di Indonesia dalam mengambil kebijakan untuk menetapkan berapa standar fee audit yang ideal. Keempat, Mendorong untuk menambah Kantor Akuntan Publik di Indonesia, sehingga rasio antara Perusahaan sektor UMKM sebanding dengan Kantor Akuntan Publik di Indonesia dan tidak terjadi lagi ketidak seimbangan antara permintaan dan penawaran. Kelima, Mengkaji sejauh mana penerapan Undang undang No. 40 Tahun 2007 tentang kewajiban perusahaan sektor UMKM untuk diaudit dengan tujuan laporan keuangan menjadi transparan dan akuntabel, walaupun selama ini perusahaan sektor UMKM tidak wajib untuk mempublikasikan laporan keuangannya.

\section{TINJAUAN PUSTAKA DAN PENGEMBANGAN HIPOTESIS Ukuran Perusahaan berpengaruh terhadap Audit Fee.}

Ukuran perusahaan adalah salah satu atribut utama yang digunakan oleh sebagian besar peneliti sebelum menentukan apa yang menentukan fee audit. Bukti dari sudi ini menemukan bahwa perusahaan besar cenderung untuk membayar fee audit lebih tinggi dari perusahaan kecil (Anderson \& Zeghal,1994; Mike et al, 1997; Ashbaugh et al,2003; Whisenant, et al, 2003; Naser \& Nuseibh, 2008; Ellis \& Booker, 2011; Hassandan Nase,2013; Ulhaq \& Leghari, 2015). Banyak alasan yang menjelaskan 
bahwa perusahaan yang besar biaya keagenan tinggi yang dihasilkan dari potensi konflik antara manajemen dengan stakeholder (Inchausti, 1997).

$\mathrm{H}_{1}$ : Ukuran Perusahaan berpengaruh terhadap Audit Fee.

\section{Profitabilitas berpengaruh terhadap Audit Fee.}

banyak mengungkapkan bahwa perusahaan melaporkan keuntungan yang lebih tinggi, karena akan menunjukkan efisiensi manajemen perusahan dalam mengalokasikan sumber daya yang tersedia, dan manajemen perusahaan cenderung mengungkapkan informasi lebih lanjut untuk melihatkan kinerja perusahaan dan mengurangi biaya agensi (Watts \& Zimmerman, 1986) dan untuk memperkuat posisi dan kompensasi (Inchausti, 1997).

$\mathrm{H}_{2}$ : Profitabilitas berpengaruh terhadap Audit Fee

\section{Resiko Perusahaan berpengaruh terhadap Audit Fee.}

Menurut teori keagenan, perusahaan yang sangat tinggi leveragenya harus diungkapkan informasinya lebih banyak dalam rangka memenuhi kebutuhan krediturnya (Jansen \& Meckling, 1976). Secara umum struktur modal perusahaan sangat diarahkan untuk stabil karena tingkat resiko perusahaan diukur dengan rasio leverage. Perusahaan akan mengalami resiko kebangkrutan jika mereka gagal dalam memenuhi kewajiban jangka pendek termasuk kewajiban jangka pendek yang berasal dari bunga pinjaman. Oleh karena itu auditor eskternal akan memakan waktu yang cukup lebih dalam masa auditnya untuk melakukan pemeriksaannya. Semakin banyak waktu dalam pengerjaannya maka fee audit juga semakin tinggi. Dengan demikian resiko perusahaan berhubungan positif dengan fee audit (Francis \& Simon, 1987; Craswell \& Francis, 1999), (Simunic, 1980; Francis \& Stokes, 1986; Josh \&
Bastaki, 2000; Gonthier Besacier \& Schatt,2007).

$\mathrm{H}_{3}$ : Resiko Perusahaan berpengaruh terhadap Audit Fee.

\section{Kompleksitas berpengaruh terhadap Audit Fee.}

Banyak peneliti menemukan sebelumnya salah satu penentu dominan fee audit adalah kompleksitas. Bahkan peneliti melihat ada hubungan yang signifikan dan positif antara kompleksitas klien dengan fee audit (Simunic, 1980; Brinn et al, 1994' Cameran, 2005; Josh \& Bastaki, 2000, Clatworthy \& Peel, 2006, Thinggaard \& Kiertzner, 2008; Vermeer et al, 2009; Ellis \& Booker, 2011; Verbruggen et al, 2011). Hal ini wajar karena perusahaan yang kompleksitas lebih lama masa auditnya dengan perusahaan yang tidak kompleks sehingga memerlukan fee audit yang tinggi (Sandra \& Patrick, 1996; Hoitash et al, 2007; Hackenbrack \& Knechel, 1997).

$\mathrm{H}_{4}$ : Kompleksitas berpengaruh terhadap Audit Fee.

\section{Jenis Industri berpengaruh terhadap Audit Fee.}

Jenis industri juga merupakan salah satu indikator penentuan fee audit. Jenis industri tertentu memerlukan waktu yang cukup dibandingkan dengan industri lainnya. Hal ini akan mengakibatkan fee audit lebih tinggi dibandingkan dengan perusahaan industri lainnya (Firth, 1985; Anderson \& Zeghal, 1994). Misalnya perusahaan manufaktur lebih cenderung mengungkapkan informasinya dibandingkan dengan perusahaan non manufaktur (Camfferman \& Cooke, 2002, Naser \& Nuseibeh, 2008).

$\mathrm{H}_{5}$ : Jenis Industri berpengaruh terhadap Audit Fee.

\section{Status Kantor Akuntan Publik berpengaruh terhadap Audit Fee.}

Peneliti banyak yang setuju bahwa kantor akuntan publik yang berafiliasi dengan luar negeri memiliki kualitas audit 
yang tinggi (Lennox, 1999). Kantor akuntan publik yang mengaudit perusahaan besar juga lebih tinggi dibandingkan perusahaan kecil dan biasanya lebih baik dibandingkan dengan kantor akuntan publik yang mengaudit perusahaan kecil (Hay et al, 2006), sehingga kantor akuntan publik yang mengaudit perusahaan kecil dianggap masih kecil (De Angelo, 1981; Haniffa \& Cooke, 2002; Glaum \& Street, 2003).

$\mathrm{H}_{6}$ : Status Kantor Akuntan Publik berpengaruh terhadap Audit Fee

\section{METODE PENELITIAN}

\section{Analisis Statistik Deskriptif}

Analisis statistik deskriptif memberikan gambaran atau deskripsi suatu data yang dilihat dari nilai minimum, maksimum, rata-rata (mean), standar deviasi dari masing-masing variabel penelitian. Analisis statistik deskriptif dalam penelitian ini meliputi nilai minimum, maksimum, mean, dan standar deviasi atas variabel yang digunakan penelitian yang terdiri dari ukuran perusahaan (UKURAN), profitabilitas perusahaan (PROF), resiko perusahaan (RESIKO), kompleksitas (COMP), jenis industry (INDS), status KAP (AUST), dan audit fee (ADFEES).

\section{Tabel 1}

\section{Statistik Deskriptif}

\begin{tabular}{|c|r|r|r|r|r|}
\hline Variabel & N & MIN & MAX & MEAN & $\begin{array}{c}\text { STD. } \\
\text { DEVIATION }\end{array}$ \\
\hline UKURAN & 34 & 8,98 & 10,86 & 9,98 & 0,49 \\
\hline PROF & 34 & 0 & 0,92 & 0,20 & 0,19 \\
\hline RESIKO & 34 & 0 & 0,94 & 0,43 & 0,31 \\
\hline AUST & 34 & 0 & 1 & 0,85 & 0,35 \\
\hline INDS & 34 & 0 & 1 & 0,20 & 0,41 \\
\hline COMP & 34 & 0 & 1 & 0,08 & 0,28 \\
\hline ADFEES & 34 & 16,12 & 17,37 & 16,58 & 0,24 \\
\hline
\end{tabular}

Sumber : Data sekunder yang diolah, 2019

Tabel 1 diatas, menggambarkan deskripsi variabel-variabel yang digunakan dalam penelitian ini. Minimum adalah nilai terkecil dari suatu rangkaian pengamatan, maksimum adalah nilai terbesar dari suatu rangkaian pengamatan, mean (rata-rata) adalah hasil penjumlahan nilai dibagi seluruh data dibagi dengan banyaknya data, sementara standar deviasi adalah akar dari jumlah kuadrat dari selisih nilai data dengan rata-rata dibagi dengan banyaknya data.

Statistik deskriptif pada tabel 1 dapat diketahui bahwa variabel ukuran perusahaan (UKURAN) dari 34 sampel memiliki rata-rata 9,98. Nilai minimum ukuran perusahaan (UKURAN) pada penelitian ini adalah 8,98. Nilai maksimum ukuran perusahaan (UKURAN) pada penelitian ini adalah 10,86.

Variabel profitabilitas perusahaan (PROF) pada statistik deskriptif tabel 1 menggambarkan bahwa profitabilitas EMKM pada 34 sampel penelitian memiliki rata-rata 0,20 . Nilai minimum profitabilitas perusahaan (PROF) pada penelitian ini adalah 0 . Nilai maksimum profitabilitas perusahaan (PROF) dalam penelitian ini adalah 0,92 .

Statistik deskriptif pada tabel 1 dapat diketahui bahwa resiko perusahaan (RESIKO) memiliki rata-rata 0,43. Nilai minimum resiko perusahaan (RESIKO) pada penelitian ini adalah 0 . Nilai maksimum dalam penelitian ini adalah 0,94 .

Variabel status KAP (AUST) pada statistik deskriptif tabel 1 menggambarkan bahwa rata-rata status KAP yang digunakan 34 sampel EMKM dalam penelitian ini adalah 0,85 . Nilai minimum sebesar 0 untuk KAP yang berafiliasi dan nilai maksimum sebesar 1 untuk KAP yang tidak berafiliasi.

Statistik deskriptif pada tabel 1 dapat diketahui bahwa jenis industry (INDS) pada sampel penelitian memiliki rata-rata sebesar 0,29 . Nilai minimum jenis industry (INDS) dalam penelitian ini adalah 0 . Nilai maksimumnya adalah 1 .

Berdasarkan statistik deskriptif pada tabel 1 dapat diketahui bahwa variabel kompleksitas perusahaan (COMP) dalam penelitian ini memiliki rata-rata sebesar 0,08 . Nilai minimum 0 dan nilai maksimum sebesar 1 .

Variabel audit fee (ADFEES) pada statistik deskriptif tabel 1 menggambarkan 
bahwa rata-rata audit fee sebesar logaritma natural 16,58 atau memiliki rata-rata audit fee sebesar $\mathrm{Rp} 16.558 .824,-$ nilai minimum sebesar $\mathrm{Rp}$ 10.000.000,- dan nilai maksimum sebesar Rp 35.000.000,-.

\section{Uji Persamaan}

Dalam penelitian ini menggunakan model regresi sebagai berikut:

ADFEES = f (SIZE, PROF, RESIKO, COM, INDS, AUSTR, ARL, ADCOM)

\section{Dimana:}

ADFEES : Audit Fee yang diukur dengan logaritma natural dari biaya audit

(+) UKURAN : Ukuran perusahaan yang diukur dengan logaritma natural dari total aset perusahaan

(+) PROF : Profitabilitas diukur dengan laba dibagi dengan penjualan

(+) RESIKO : Resiko diukur dengan total kewajiban dibagi dengan total aset

(+) COMP : Kompleksitas Perusahaan diukur dengan memiliki atau tidak anak perusahaan. Jika memiliki $=1$, jika tidak $=0$.

(+) INDS : Industri diukur dengan jika Industri $=1$, Jika tidak $=0$

(+) AUST : Status KAP diukur dengan, Jika KAP Berafiliasi $=0$, dan jika tidak $=1$

\section{Uji Normalitas Data}

Tabel 2 Hasil Uji Normalitas ukuran perusahaan, profitabilitas perusahaan, resiko perusahaan, kompleksitas perusahaan, jenis industrim, status KAP terhadap audit fee.
Tabel 2

Normalitas Data

\begin{tabular}{|c|c|c|}
\hline & $\begin{array}{c}\text { Thidndadized } \\
\text { Feshud }\end{array}$ & Eeter argat \\
\hline$X$ & 34 & \multirow{3}{*}{$\begin{array}{c}\text { Data tertistribusi } \\
\text { nonual }\end{array}$} \\
\hline Kotnogat or-Strifflov 2 & $3 ? 79$ & \\
\hline 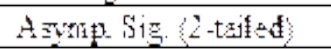 & 3.200 & \\
\hline
\end{tabular}

Sumber : Data sekunder yang diolah, 2019

Hasil dari pengujian KolmogorovSmirnov di atas, nilai signifikan yang diperoleh lebih dari 0,05 atau 0,200 > 0,05 . Hal ini menunjukkan bahwa model regresi berdistribusi normal dan memenuhi asumsi normalitas karena tingkat signifikansi melebihi $\alpha=0,05$.

\section{Uji Multikolinearitas}

Tabel 3 Hasil Uji Multikolinearitas ukuran perusahaan, profitabilitas perusahaan, resiko perusahaan, kompleksitas perusahaan, jenis industry, status KAP terhadap audit fee.

\section{Tabel 3}

Uji Multikolinearitas

\begin{tabular}{|c|c|c|c|}
\hline Variabel & Tolerance & VIF & Keterangan \\
\hline UKURAN & 0,751 & 1,332 & \multirow{5}{*}{$\begin{array}{c}\text { Tidak terjadi } \\
\text { multikolinearitas }\end{array}$} \\
\hline PROF & 0,870 & 1,149 & \\
\hline RESIKO & 0,811 & 1,232 & \\
\hline AUST & 0,773 & 1,293 & \\
\hline INDS & 0,838 & 1,193 & \\
\hline COMP & 0,874 & 1,144 & \\
\hline
\end{tabular}

Sumber: Data sekunder yang diolah, 2019

Berdasarkan tabel 3, hasil pengujian multikolinearitas menunjukkan keseluruhan nilai Tolerance variabel ukuran perusahaan, profitabilitas perusahaan, resiko perusahaan, kompleksitas perusahaan, jenis industri, status KAP di atas $0,10(>0,10)$. Hasil perhitungan VIF (Variance Inflation Factor) juga menunjukkan nilai keseluruhan variabel ukuran perusahaan, profitabilitas perusahaan, resiko perusahaan, kompleksitas perusahaan, jenis industrim, status KAP di bawah $10(\leq$ 10). Dengan demikian dapat disimpulkan bahwa model persamaan tidak mengalami gangguan multikolinearitas. 


\section{Uji Autokorelasi}

Tabel 4 Hasil Uji Autokorelasi ukuran perusahaan, profitabilitas perusahaan, resiko perusahaan, kompleksitas perusahaan, jenis industry, status KAP terhadap audit fee.

\section{Tabel 4}

Uji Autokorelasi

\begin{tabular}{|c|c|c|}
\hline Model Summary & Nilai & Keterangan \\
\hline $\mathrm{k} ; \mathrm{N}$ & $6 ; 34$ & \multirow{4}{*}{$\begin{array}{l}\text { Tidak terjadi } \\
\text { autokorelasi }\end{array}$} \\
\hline DU & 1,80758 & \\
\hline 4-DU & 2,19242 & \\
\hline Durbin-Watson & 1,915 & \\
\hline
\end{tabular}

Sumber: Data sekunder yang diolah, 2019

Berdasarkan tabel 4 hasil uji autokorelasi menunjukkan nilai DurbinWatson sebesar 1,915, nilai ini dibandingkan dengan nilai tabel pada tingkat signifikansi 5\%, jumlah sampel 34 (n) dan jumlah variabel independen 6 $(\mathrm{k}=6)$, maka di tabel Durbin-Watson akan didapatkan nilai batas atas $(\mathrm{du})=1,80758$ dan $4-d u=2,19242$. Karena nilai DW 1,917 lebih besar dari batas atas (du) 1,80758 dan kurang dari 4 - 1,80758 (4 du), maka dapat disimpulkan bahwa tidak terdapat autokorelasi pada persamaan ini.

\section{Uji Heteroskedastisitas}

Tabel 5 Hasil Uji Heteroskedastisitas ukuran perusahaan, profitabilitas perusahaan, resiko perusahaan, kompleksitas perusahaan, jenis industry, status KAP terhadap audit fee.

\section{Tabel 5}

\section{Uji Heteroskedastisitas}

\begin{tabular}{|l|r|r|r|}
\hline \multicolumn{1}{|c|}{ Model } & \multicolumn{1}{c|}{ T } & Sig. & Keterangan \\
\hline UKURAN & 0,748 & 0,461 & \\
\cline { 1 - 2 } PROF & $-0,948$ & 0,352 & \multirow{2}{*}{ Tidak terjadi } \\
heteroskedast \\
RESIKO & 0,946 & 0,352 & isitas \\
\hline AUST & 2,991 & 0,006 & \\
\cline { 1 - 2 } INDS & $-2,363$ & 0,026 & \\
\cline { 1 - 2 } COMP & $-1,290$ & 0,208 & \\
\cline { 1 - 2 } & & &
\end{tabular}

Sumber: Data sekunder yang diolah, 2019

Berdasarkan tabel 5 terlihat hasil uji heteroskedastisitas melalui uji Glejser yang menunjukkan nilai signifikasi masing-masing variabel independen lebih besar dari 0,05 (>5\%). Dengan demikian dapat disimpulkan model persamaan yang digunakan dalam penelitian ini tidak mengandung gangguan heteroskedastisitas.

\section{Uji Koefisien Determinasi}

Koefisien determinasi (Adj $\mathrm{R}^{2}$ ) pada intinya mengukur seberapa jauh kemampuan model dalam menerangkan variasi variabel dependen. Nilai koefisien determinasi adalah antara nol dan satu (Ghozali, 2016). Pengujian ini bertujuan untuk mengetahui tingkat ketepatan yang paling baik didalam suatu analisis regresi. Pada hasil perhitungan statistik maka diperoleh nilai Adj $R$ Square sebagai berikut:

\section{Tabel 6}

Uji Koefisien Determinasi

\begin{tabular}{|l|}
\hline \multicolumn{1}{|c|}{ Model Summary } \\
\hline \multicolumn{1}{|c|}{ Adjusted R Square } \\
\hline 0,214 \\
\hline Predictors: (Constant), COMP, RESIKO, AUST, \\
PROF, INDS, UKURANS \\
\hline Dependent Variable: ADFEES \\
\hline
\end{tabular}

Sumber: Data sekunder yang diolah, 2019

Tabel 6 menunjukkan bahwa nilai koefisien determinasi yang menunjukkan nilai Adj R-Square sebesar 0,214. Hal ini berarti variabel audit fee yang di proksi dengan ADFEES sebesar 21,4\% dapat dijelaskan oleh ukuran perusahaan, profitabilitas perusahaan, resiko perusahaan, kompleksitas perusahaan, jenis industry, status KAP. Sedangkan $78,6 \%$ variabel audit fee dapat dijelaskan oleh variabel lain.

\section{Uji Signifikansi (Uji F)}

Uji $F$ bertujuan untuk menguji apakah model regresi yang digunakan dalam penelitian baik atau tidak. Jika model signifikan, maka model dapat digunakan untuk prediksi. Pengujian dilakukan dengan menggunakan signifikan level 0,05 dan mencari nilai $F$ tabel yang nilainya 
lebih kecil dari nilai $\mathrm{F}$ hitung. Hasil uji $\mathrm{F}$ dapat dilihat sebagai berikut:

Tabel 7

Uji Statistik F

\begin{tabular}{|c|c|}
\hline \multicolumn{2}{|c|}{ ANOVA $^{\mathbf{a}}$} \\
\hline Fhitung & Sig. \\
\hline 2,600 & 0,047 \\
\hline Dependent Variable: ADFEES \\
\hline \multicolumn{2}{|c|}{ Predictors: (Constant), COMP, } \\
RESIKO, AUST, PROF, INDS, \\
UKURAN \\
\hline
\end{tabular}

Sumber: Data sekunder yang diolah, 2019

Berdasarkan tabel diatas menunjukkan bahwa nilai $\mathrm{F}$ hitung sebesar 2,600 dengan nilai signifikansi 0,047 lebih kecil dari 0,05 . Terlihat bahwa nilai $F$ hitung sebesar 2,600 dan $\mathrm{F}$ tabel untuk df (34) sebesar 2,558, yang artinya F hitung > $F$ tabel $(2,600>2,558)$ atau dengan kata lain hipotesis nol (H0) ditolak. Maka dapat disimpulkan bahwa variabel independen secara serentak berpengaruh terhadap variabel dependen.

\section{Hasil Uji Hipotesis}

\section{Tabel 8}

\section{Uji Hipotesis}

\begin{tabular}{|l|l|l|l|l|l|l|}
\hline & \multicolumn{1}{|c|}{$\boldsymbol{B}$} & $\begin{array}{c}\text { Standar } \\
\text { Error }\end{array}$ & $\boldsymbol{B}$ & $\boldsymbol{t}$ & Sig. & $\begin{array}{c}\text { Keterang } \\
\text { an }\end{array}$ \\
\hline Ukuran & 0,171 & 0,088 & 0,345 & 1,936 & 0,063 & Ditolak \\
\hline Prof & $-0,220$ & 0,204 & $-0,178$ & $-1,078$ & 0,291 & Ditolak \\
\hline Resiko & 0,301 & 0,134 & 0,386 & 2,253 & 0,033 & Diterima \\
\hline Aust & 0,192 & 0,120 & 0,281 & 1,602 & 0,121 & Ditolak \\
\hline Inds & $-0,193$ & 0,101 & $-0,322$ & $-1,912$ & 0,067 & Ditolak \\
\hline Comp & $-0,064$ & 0,141 & $-0,075$ & $-0,457$ & 0,651 & Ditolak \\
\hline Constant & 14,678 & 0,910 & & 16,122 & 0,000 & \\
\hline
\end{tabular}

Sumber: Data sekunder yang diolah, 2019

\section{PEMBAHASAN}

\section{Ukuran Perusahaan berpengaruh terhadap Audit Fee.}

Berdasarkan tabel diatas, hasil pengujian variabel ukuran perusahaan (UKURAN) terhadap audit fee (ADFEES) memiliki nilai koefisien regresi variabel sebesar 0,171 bernilai positif. Hasil pengolahan data dapat dilihat nilai $t$ hitung sebesar 1,936 sedangkan $t$ tabel pada signifikansi 0,05 sebesar 2,032, sehingga $t$ hitung < t tabel $(1,936<2,032)$. Selain itu, dapat dilihat nilai probabilitas signifikansi sebesar 0,063 atau lebih besar dari 0,05 $(0,063>0,05)$. Hasil uji hipotesis di atas menunjukkan bahwa variabel ukuran perusahaan tidak berpengaruh positif terhadap audit fee. Ini berarti bahwa hipotesis pertama yang menyebutkan bahwa variabel ukuran perusahaan berpengaruh positif terhadap audit fee ditolak.

\section{Profitabilitas berpengaruh terhadap Audit Fee.}

Variabel profitabilitas perusahaan (PROF) terhadap audit fee (ADFEES) memiliki nilai koefisien regresi variabel sebesar $-0,220$ bernilai negatif. Hasil pengolahan data dapat dilihat nilai t hitung sebesar -1,078 sedangkan $\mathrm{t}$ tabel pada signifikansi 0,05 sebesar 2,032, sehingga $\mathrm{t}$ hitung $<\mathrm{t}$ tabel $(-1,078<2,032)$. Selain itu, dapat dilihat nilai probabilitas signifikansi sebesar 0,291 atau lebih besar dari $0,05(0,291>0,05)$. Hasil uji hipotesis di atas menunjukkan bahwa variabel profitabilitas perusahaan tidak berpengaruh positif terhadap audit fee. Ini berarti bahwa hipotesis kedua yang menyebutkan bahwa variabel profitabilitas perusahaan berpengaruh positif terhadap audit fee ditolak. Sejalan dengan penelitian Naser, K \& Nuseibeh, R (2008) yang tidak menemukan hubungan yang signifikan antara profitabilitas perusahaan dengan audit fee.

\section{Resiko Perusahaan berpengaruh terhadap Audit Fee.}

Variabel resiko perusahaan

(RESIKO) terhadap audit fee (ADFEES) memiliki nilai koefisien regresi variabel sebesar 0,301 bernilai positif. Hasil pengolahan data dapat dilihat nilai t hitung sebesar 2,253 sedangkan $t$ tabel pada signifikansi 0,05 sebesar 2,032, sehingga $t$ hitung $>\mathrm{t}$ tabel $(2,253>2,032)$. Selain itu, dapat dilihat nilai probabilitas signifikansi sebesar 0,033 atau lebih kecil dari 0,05 $(0,033<0,05)$. Hasil uji hipotesis di atas menunjukkan bahwa variabel resiko perusahaan berpengaruh positif terhadap 
audit fee. Ini berarti bahwa hipotesis ketiga yang menyebutkan bahwa variabel resiko perusahaan berpengaruh positif terhadap audit fee diterima. Hal ini berarti perusahaan membayar jasa audit yang lebih besar, ketika resiko yang dimiliki perusahaan juga besar.

\section{Kompleksitas berpengaruh terhadap Audit Fee.}

Variabel kompleksitas perusahaan (COMP) terhadap audit fee (ADFEES) memiliki nilai koefisien regresi variabel sebesar $-0,064$ bernilai negatif. Hasil pengolahan data dapat dilihat nilai t hitung sebesar -0,457 sedangkan $\mathrm{t}$ tabel pada signifikansi 0,05 sebesar 2,032, sehingga $t$ hitung $<\mathrm{t}$ tabel $(-0,457<2,032)$. Selain itu, dapat dilihat nilai probabilitas signifikansi sebesar 0,651 atau lebih besar dari $0,05(0,651>0,05)$. Hasil uji hipotesis di atas menunjukkan bahwa variabel kompleksitas perusahaan tidak berpengaruh positif terhadap audit fee. Ini berarti bahwa hipotesis keempat yang menyebutkan bahwa variabel kompleksitas perusahaan berpengaruh positif terhadap audit fee ditolak. Sejalan dengan penelitian Rukmana et al (2017) dan Cristansy \& Ardiati (2018) yang juga tidak menemukan hubungan antara kompleksitas perusahaan dengan audit fee.

\section{Jenis Industri berpengaruh terhadap Audit Fee.}

Variabel jenis industry (INDS) terhadap audit fee (ADFEES) memiliki nilai koefisien regresi variabel sebesar 0,193 bernilai negatif. Hasil pengolahan data dapat dilihat nilai t hitung sebesar 1,912 sedangkan $t$ tabel pada signifikansi 0,05 sebesar 2,032, sehingga $t$ hitung $<\mathrm{t}$ tabel $(-1,912<2,032)$. Selain itu, dapat dilihat nilai probabilitas signifikansi sebesar 0,067 atau lebih besar dari 0,05 $(0,067>0,05)$. Hasil uji hipotesis di atas menunjukkan bahwa variabel jenis industry tidak berpengaruh positif terhadap audit fee. Ini berarti bahwa hipotesis kelima yang menyebutkan bahwa variabel jenis industri berpengaruh positif terhadap audit fee ditolak. Sejalan dengan penelitian Sinaga \& Rachmawati (2018) dan Naser \& Nuseibeh (2008) yang menunjukkan bahwa jenis industri tidak memiliki pengaruh positif terhadap audit fee.

\section{Status Kantor Akuntan Publik berpengaruh terhadap Audit Fee. \\ Variabel status KAP (AUST)} terhadap audit fee (ADFEES) memiliki nilai koefisien regresi variabel sebesar 0,192 bernilai positif. Hasil pengolahan data dapat dilihat nilai $\mathrm{t}$ hitung sebesar 1,602 sedangkan $t$ tabel pada signifikansi 0,05 sebesar 2,032, sehingga $\mathrm{t}$ hitung $<\mathrm{t}$ tabel $(1,602<2,032)$. Selain itu, dapat dilihat nilai probabilitas signifikansi sebesar 0,121atau lebih besar dari 0,05 $(0,121>0,05)$. Hasil uji hipotesis di atas menunjukkan bahwa variabel status KAP tidak berpengaruh positif terhadap audit fee. Ini berarti bahwa hipotesis keenam yang menyebutkan bahwa variabel status KAP berpengaruh positif terhadap audit fee ditolak. Sejalan dengan penelitian Suharli \& Nurlelah (2008) dan Hassan \& Naser (2013) yang juga menyatakan tidak ada hubungan antara status KAP dan audit fee.

\section{Kesimpulan}

Berdasarkan hasil penelitian, maka penulis dapat mengambil kesimpulan sebagai berikut:

1. Ukuran perusahaan tidak berpengaruh positif terhadap audit fee. Hasil tersebut didasarkan kepada kriteria pengujian hipotesis, jika nilai $\mathrm{t}$ hitung sebesar 1,936 sedangkan $\mathrm{t}$ tabel pada signifikansi 0,05 sebesar 2,032, sehingga $\mathrm{t}$ hitung $<\mathrm{t}$ tabel $(1,936<$ 2,032). Artinya semakin kecil ukuran perusahaan semakin kecil pula audit fee.

2. Profitabilitas perusahaan tidak berpengaruh positif terhadap audit fee. Hasil tersebut didasarkan kepada kriteria pengujian hipotesis, jika nilai $\mathrm{t}$ 
hitung sebesar -1,078 sedangkan t tabel pada signifikansi 0,05 sebesar 2,032, sehingga $\mathrm{t}$ hitung $<\mathrm{t}$ tabel $(-1,078<$ 2,032). Artinya semakin kecil profitabilitas perusahaan maka semakin kecil pula audit fee.

3. Resiko perusahaan berpengaruh positif terhadap audit fee. Hasil tersebut didasarkan kepada kriteria pengujian hipotesis, jika nilai $\mathrm{t}$ hitung sebesar 2,253 sedangkan $t$ tabel pada signifikansi $\quad 0,05$ sebesar 2,032, sehingga $\mathrm{t}$ hitung $>\mathrm{t}$ tabel $(2,253>$ 2,032). Artinya semakin besar resiko perusahaan maka semakin besar pula audit fee.

4. Kompleksitas perusahaan tidak berpengaruh positif terhadap audit fee. Hasil tersebut didasarkan kepada kriteria pengujian hipotesis, jika nilai t hitung sebesar $-0,457$ sedangkan t tabel pada signifikansi 0,05 sebesar 2,032, sehingga $\mathrm{t}$ hitung $<\mathrm{t}$ tabel $(-0,457<$ 2,032). Artinya semakin kecil kompleksitas perusahaan maka semakin kecil pula audit fee.

5. Jenis industry tidak berpengaruh positif terhadap audit fee. Hasil tersebut didasarkan kepada kriteria pengujian hipotesis, jika nilai t hitung sebesar 1,912 sedangkan $t$ tabel pada signifikansi 0,05 sebesar 2,032, sehingga $\mathrm{t}$ hitung $<\mathrm{t}$ tabel $(-1,912<$ 2,032). Artinya semakin besar jenis industry maka semakin besar pula audit fee.

6. Status KAP tidak berpengaruh positif terhadap audit fee. Hasil tersebut didasarkan kepada kriteria pengujian hipotesis, jika nilai $\mathrm{t}$ hitung sebesar 1,602 sedangkan $t$ tabel pada signifikansi $\quad 0,05$ sebesar 2,032, sehingga $\mathrm{t}$ hitung $<\mathrm{t}$ tabel $(1,602<$ 2,032). Artinya kecil status Kantor Akuntan Publik maka semakin kecil pula audit fee.

\section{DAFTAR PUSTAKA}

Abbott, L. J., Parker, S., Peters, G. F., \& Raghunandan, K. (2003). The association between audit committee characteristics and audit fees. Auditing: A Journal of Practice \& Theory, 22(2). 1732.

Abdullah Awadh Bukair, Azhar Abdul Rahman . (2015). Bank performance and board of directors attributes by Islamic banks. International Journal of Islamic and Middle Eastern Finance and Management, 8 (3), 291 - 309.

Aburime Uhomoibhi Toni. (2009). Impact of Corruption on Bank Profitability in Nigeria. EuroEconomica , 2,50-57.

Alanazi, Ahmed; Liu, B; Forster, J. (2011). The financial performance of Saudi Arabian IPOs.International journal of Islamic and Middle Eastern Finance and Management,4 (2), 12.

Amba, M. S. and Almukharreq, F. (2013). Impact of the Financial Crisis on Profitability of the Islamic Banks vs Conventional BanksEvidence from GCC. International Journal of Financial Research, 4(3), 83-93.

Anderson, T., \& Zeghal, D. (1994). The pricing of audit services: Further evidence from the Canadian market, Accounting and Business Research, 24 (95), 195-207.

Ashbaugh, H., LaFond, R., \& Mayhew, B. W. (2003). Do nonaudit services compromise auditor independence? Further evidence. 
The Accounting Review, 78(3), 611-639.

Audousset-Coulier, S. (2015). Audit fees in a joint audit setting. European Accounting Review, 24(2), 347-377.

Ball, R. (2001). Infrastructure requirements for an economically enceinte system of publicfinancial reporting and disclosure. Brookings-Wharton Papers on Financial Services, 1,127-169. Bamber, E. M., Bamber, L. S., \& Schoderbek, M. P. (1993). Audit structure and other determinants of audit report lag-an empiricalanalysis. Auditing-a journal of practice \& theory, 12(1), 1-23 .

Barako, D. G., Hancock, P., \& Izan, H. Y. (2006). Factors influencing voluntary corporate disclosure by Kenyan companies, Corporate Governance: An International Review, 14 (2), 107-125.

Basioudis, I. G., \& Fifi, F. (2004). The market for professional services in Indonesia.

International Journal of Auditing, 8 (2), 153-164.

Beasley, M. S., \& Salterio, S. E. (2001). The Relationship between Board Characteristics and Voluntary Improvements in Audit Committee Composition and Experience. Contemporary Accounting Research, 18(4), 539-570 .

Beatty, R. P. (1989). Auditor reputation and the pricing of initial public offerings. Accounting Review, 693-709.
Becker, C. L., DeFond, M. L., Jiambalvo, J., \& Subramanyam, K. (1998). The Effect of Audit Quality on Earnings Management. Contemporary accounting research, 15(1), 1-24 .

Black, B. (2001). The legal and institutional preconditions for strong Securities Markets.UCLA Law Review, 48, 781-856.

Brinn, T., Peel, M. J., \& Roberts, R. (1994). Audit fee determinants of independent \& subsidiary unquoted companies in the UK - an exploratory study. The British Accounting Review, 26 (2), 101-121.

Bryman, A., \& Cramer, D. (2005). Quantitative data analysis with SPSS 12 and 13: A guide for social scientist: Routledge.

Cameran, M. (2005). Audit fees and the large auditor premium in the Italian market, International Journal of Auditing, 9 (2), 129146. Camfferman, K., \& Cooke, T. E. (2002). An analysis of disclosure in the annual reports of UK and Dutch companies. Journal of International Accounting Research, 1 (1), 330 .

Carson, E., Fargher, N., Simon, D. T., \& Taylor, M. H. (2004). Audit fees and market segmentationfurther evidence on how client size matters within the context of audit fee models. International Journal of Auditing, 8 (1), 79-91.

Chan, P., Ezzamel, M., \& Gwilliam, D. (1993). Determinants of audit fees for quoted UK companies, 
Journal of Business Finance \& Accounting, 20 (6), 765-786.

Chandra, M.O. (2015). Pengaruh Good Corporate Governance, Karakteristik Perusahaan dan Ukuran KAP terhadap Fee Audit Eksternal. Jurnal Akuntansi Bisnis Vol. XIII.

Chatterjee, B., \& Mir, M. Z. (2008). The current status of environmental reporting by Indian companies, Managerial Auditing Journal, 23 (6), 609-629.

Che Ahmad. A. \& Derashid. C. (1996 July). The Pricing of audit services: Evidence from the Kuala Lumpur stock exchange (KLSE) listed companies, Journal Analysis, 4 (1), 4-45.

Choi, J.-H., Kim, C., Kim, J.-B., \& Zang, Y. (2010). Audit office size, audit quality, and audit pricing, Auditing: A Journal of Practice \& Theory, 29(1), 73-97. Clatworthy, M. A., \& Peel, M. J. (2006). The effect of corporate status on external audit fees: Evidence from the UK, Journal of Business Finance and Accounting, 1(2), 169-201. Collier, P., \& Gregory, A. (1996). Audit committee effectiveness and the audit fee, European Accounting Review, 5(2), 177198.

Cormier, D., \& Magnan, M. (2003). Environmental reporting management: a continental European perspective. Journal of Accounting and Public Policy, 22(1), 43-62.

Craswell, A. T., \& Francis, J. R. (1999). Pricing initial audit engagements: A test of competing theories, The
Accounting Review, 74 (2), 201 216.

Cristansy, Jesslyn \& Ardiati Y.A. (2018). Pengaruh kompleksitas perusahaan, ukuran perusahaan, dan ukuran KAP terhadap fee audit pada perusahaan manufaktur yang terdaftar di BEI tahun 20122016. MODUS Vol.30 (2):198211.

DeAngelo, L. E. (1981). Auditor size and audit quality, Journal of Accounting and Economics, 3 (3), 183-199.

Dye, R. A. (1993). Auditing standards, legal liability, and auditor wealth. Journal of political Economy, 887-914.

Ellis, Y., \& Booker, Q. L. (2011). Audit fee determinants in the nonprofit sector: A study of community action agencies, Faculty Publications, Columbia State University

Ezzamel, M., Gwilliam, D. R., \& Holland, K. M. (1996). Some empirical evidence from publicly quoted UK companies on the relationship between the pricing of audit and non-audit services, Accounting and Business Research, 27 (1), 316.

Ezzamel, M., Gwilliam, D. R., \& Holland, K. M. (2002). The Relationship between Categories of Non-Audit Services and Audit Fees: Evidence from UK Companies. International Journal of Auditing, 6 (1), 13-35.

Firth, M. (1985). An analysis of audit fees and their determinants in New Zealand, Auditing: A Journal of Practice and Theory, 4 (2), 2337. 
Francis, J. R., \& Simon, D. T. (1987). A test of audit pricing in the smallclient segment of the US audit market. Accounting Review, 62(1), 145-157.

Francis, J. R., \& Stokes, D. J. (1986). Audit prices, product differentiation, and scale economies: further evidence from the Australian market, Journal of Accounting Research, 24, 383393.

Ezzamel, M., Gwilliam, D. R., \& Holland, K. M. (1996). Some empirical evidence from publicly quoted UK companies on the relationship between the pricing of audit and non-audit services, Accounting and Business Research, 27 (1), 316.

Ezzamel, M., Gwilliam, D. R., \& Holland, K. M. (2002). The Relationship between Categories of Non-Audit Services and Audit Fees: Evidence from UK Companies. International Journal of Auditing, 6 (1), 13-35.

Firth, M. (1985). An analysis of audit fees and their determinants in New Zealand, Auditing: A Journal of Practice and Theory, 4 (2), 2337.

Francis, J. R., \& Simon, D. T. (1987). A test of audit pricing in the smallclient segment of the US audit market. Accounting Review, 62(1), 145-157.

Francis, J. R., \& Stokes, D. J. (1986). Audit prices, product differentiation, and scale economies: further evidence from the Australian market, Journal of Accounting Research, 24, 383-
393. Downloaded by Cornell University Library At 11:42 30 July 2016 (PT) 21

Gerakos, J. \&Syverson,C. (2013). Competition in the audit Market: Policy implications. University of Chicago Booth School of Business: faculty publication.

Ghazali, N. A. M. (2007). Ownership structure and corporate social responsibility disclosure: some Malaysian evidence, Corporate Governance, 7 (3), 251-266.

Ghosh, A., \& Pawlewicz, R. (2009). The impact of regulation on auditor fees: Evidence from the SarbanesOxley Act. Auditing: a journal of practice \& theory, 28(2), 171-197

Glaum, M., and Street, D. L. (2003). Compliance with the disclosure requirements of Germany's new market: IAS versus US GAAP, Journal of International Financial Management and Accounting, 14, 64-100.

Goddard, A. R., \& Masters, C. (2000). Audit committees, Cadbury Code and audit fees: an empirical analysis of UK companies. Managerial Auditing Journal, 15 (7), 358-371.

Gonthier-Besacier, N., \& Schatt, A. (2007). Determinants of audit fees for French quoted firms. Managerial Auditing Journal, 22(2), 139-160.

Hackenbrack, K., \& Knechel, W. R. (1997). Resource Allocation Decisions in Audit Engagements. Contemporary Research, 14(3), 481-499. 
Hackston, D., \& Milne, M. J. (1996). Some determinants of social and environmental disclosures in New Zealand companies, Accounting, Auditing \& Accountability Journal, 9 (1), 77-108.

Haniffa, R., \& Cooke, T. (2005). The impact of culture and governance on corporate social reporting, Journal of Accounting and Public Policy, 24 (5), 391-430.

Haskins, M. E., \& Williams, D. D. (1988). The association between client factors and audit fees: A comparison by country and by firm, Accounting and Business Research, 18 (70), 183-190.

Hassan, Y, and Naser, K. (2013). Determinants of Audit Fees: Evidence from an Emerging Economy, International Business Research, pp. 13- 25.

Hay, D. (2013). Further evidence from meta-analysis of audit fee research. International Journal of Auditing, 17, 162-176. Downloaded

Hay, D. C., Knechel, W. R., \& Wong, N. (2006). Audit fees: A Metaanalysis of the effect of supply and demand attributes. Contemporary Accounting Research, 23 (1), 141-191.

Hoitash, R., Markelevich, A. and Barragato, C. A. (2007) Auditor fees and audit quality, Managerial Auditing Journal, 22(8), pp. 761786.

Hussein A. Hassan Al-Tamimi \& Husni Charif, (2011). Multiple approaches in Performance assessment of UAE commercial banks. International Journal of
Islamic and Middle Eastern Finance and Management, 4 (1), $74-82$.

Inchausti, A. G. (1997). The influence of company characteristics and accounting regulation on information disclosed by Spanish firms. European Accounting Review, 6 (1), 45-68.

Iyer, V. M., \& Iyer, G. S. (1996). Effect of Big 8 mergers on audit fees: Evidence from the United Kingdom. Auditing, 15, 123-132.

Jensen, M. C., \& Meckling, W. H. (1976). Theory of the firm: Managerial behavior, agency costs and ownership structure. Journal of financial economics, 3(4), 305360

Jin, J. Y., Kanagaretnam, K., Lobo, G. J., \& Mathieu, R. (2012). Impact of FDICIA internal controls on bank risk taking. Journal of Banking \& Finance. 614, 2013.

Johnson, E.N., Walker, K.B., Westergaard, E. (1995). Supplier concentration and pricing of audit services in New Zealand, Auditing: A Journal of Practice and Theory, 14, 74-89.

Joshi, P., \& AL-Bastaki, H. (2000). Determinants of audit fees: evidence from the companies listed in Bahrain. International journal of auditing, 4 (2), 129138.

Kikhia, Hassan Yahia, 2014. Determinants of Audit fee: Evidence from Jordan. Accounting and Finance Research, 4 (1), 42-53. Khan, M. H.-U.-Z. (2010). The effect of corporate governance elements on corporate social responsibility 
(CSR) reporting: empirical evidence from private commercial banks of Bangladesh, International Journal of Law and Management, 52 (2), 82-109. Klassen, R. D., \& Whybark, D. C. (1999). Environmental Management in Operations: The Selection of Environmental Technologies. Decision sciences, 30(3), 601-631 .

Langendijk, H. (1997). The market for audit services in the Netherlands. European Accounting Review, 6 (2), 253-264.

Lennox, C. S. (1999). Audit quality and auditor size: An evaluation of reputation and deep pockets hypotheses. Journal of Business Finance \& Accounting, 26(7-8), 779-805.

Md. Dulal Miah , Kashfia Sharmeen . (2015). Relationship between capital, risk and efficiency: A comparative study between Islamic and conventional banks of Bangladesh. International Journal of Islamic and Middle Eastern Finance and Management, 8 (2), $203-221$.

Mike, A, Mike, S., and Muhammad, H. (1997) The Determinants of External Audit Costs in the New Zealand Life Insurance Industry, Journal of International Financial Management and Accounting, 8, 69-86.

Naser, K., Al-Hussaini, A., Al-Kwari, D., \& Nuseibeh, R. (2006). Determinants of corporate social disclosure in developing countries: the case of Qatar. Advances in International Accounting, 19, 1- 23.
Naser, K., Al-Khatib, K., \& Karbhari, Y. (2002). Empirical evidence on the depth of corporate information disclosure in developing countries: the case of Jordan, International Journal of Commerce and Management, 12(3/4), 122-155.

Naser, K., \& Nuseibeh, R. (2008). Determinants of audit fees: empirical evidence from an emerging economy, International Journal of Commerce and Management, 17 (3), 239-254.

Neter, J., Wasserman, W., \& Kutner, M. H. (1989). Applied linear regression models, Homewood, IL: Irwin.

Niemi, L. (2006). Do firms pay for audit risk? Evidence on risk premiums in audit fees after direct control for audit effort, International Journal of Auditing, 6 (1), 3751.

Othman, R., \& Thani, M. Ghani (2009). Determinants of Islamic social reporting among top Shariahapproved companies in Bursa Malaysia, Research Journal of International Studies, 12, 4-20.

Owusu-Ansah, S. (1998). The impact of corporate attributes on the extent of mandatory disclosure and reporting by listed companies in Zimbabwe. The International Journal of Accounting, 33 (5), 605- 631.

Palmrose, Z. V. (1986). Audit fees and auditor size: Further evidence. Journal of Accounting Research, 24 (1), 97-110.

Pong, C. M., \& Whittington, G. (1994). The determinants of audit fees: 
Some empirical models, Journal of Business Finance \& Accounting, 21 (8), 1071-1095.

Prencipe, A. (2004). Proprietary costs and determinants of voluntary segment disclosure: evidence from Italian listed companies, European Accounting Review, 13 (2), 319-340.

Rouf, A. (2011). Corporate characteristics, governance attributes and the extent of voluntary disclosure in Bangladesh, African Journal of Business Management, 5 (19), 7836-7845.

Rukmana, M., Konde, Y.T., dan Setiawaty, A., (2017), "Pengaruh Risiko Litigasi, Corporate Governance, Karakteristik Perusahaan, dan Karakteristik Auditor Terhadap Audit Fee pada Perusahaan yang Terdaftar di BEI”, Simposium Nasional Akuntansi 20.

Sandra, W., \& Patrick, P. (1996). The determinants of audit fees in Hong Kong: An empirical study, Asian Review of Accounting, 4 (2), 32-50.

Simon, D., Teo, S. and Trompeter, G. (1992). A comparative study of the market for audit services in Hong Kong, Malaysia and Singapore, International Journal of Accounting, 27, 234-253.

Simon, D. T., \& Taylor, M. H. (2002). A survey of audit pricing in Ireland, International Journal of Auditing, 6 (1), 3-12.

Simunic, D. A. (1980). The pricing of audit services: Theory and evidence, Journal of Accounting Research, 18 (1), 161-190.
Sinaga, Evlin A. \& Rachmawati, Sistya. (2018). Besaran fee audit pada perusahaan yang terdaftar di Bursa Efek Indonesia. Media Riset Akuntansi, Auditing \& Informasi Vol 18 No. 1 April 2018: 19-34.

Suharli, Michell \& Nurlaelah. (2008). Konsentrasi auditor dan penetapan fee audit: investigasi pada BUMN. JAAI Vol. 12 No. 2, Desember 2008:133-148.

Sylvia Veronica Siregar, Yanivi Bachtiar. (2010). Corporate social reporting: empirical evidence from Indonesia Stock Exchange. International Journal of Islamic and Middle Eastern Finance and Management, 3 (3), 241 - 252

Tagesson, T., Blank, V., Broberg, P., \& Collin, S. O. (2009). What explains the extent and content of social and environmental disclosures on corporate websites: a study of social and environmental reporting in Swedish listed corporations, Corporate Social Responsibility and Environmental Management, 16 (6), 352364.

Taylor, M. E., \& Baker, R. L. (1981). An analysis of the external audit fee, Accounting and Business Research, 12, 55-60.

Thinggaard, F., \& Kiertzner, L. (2008). Determinants of audit fees: evidence from a small capital market with a joint audit requirement, International Journal of Auditing, 12 (2), 141-158.

Tower, G., Hancock, P. and Taplin, R.H. (1999). A regional study of 
listed companies' compliance with International Accounting Standards. AccountingForum, 23 (3), 293-305.

Ulhaq, A., \& Leghari, M. (2015). Determinants of audit fee in Pakistan. Research Journal of Finance and Accounting, 6(9), 176-188.

Vafeas, N., \& Waegelein, J. F. (2007). The association between audit committees, compensation incentives, and corporate audit fees, Review of Quantitative Finance and Accounting, 28(3), 241-255. Verbruggen, S., Christiaens, J., Reheul, A. M., \& Van Caneghem, T. (2011). Audit pricing in a reformed nonprofit market, HUB Research Papers.

Vermeer, T. E., Raghunandan, K., \& Forgione, D. A. (2009). Audit fees at US nonprofit organizations. Auditing: A Journal of Practice \& Theory, 28(2), 289-303.

Wallace, R. O., Naser, K., \& Mora, A. (1994). The relationship between the comprehensiveness of corporate annual reports and firm characteristics in Spain, Accounting and business research, 25, 41-53.

Wang, K., Sewon, O., and Iqbal, Z. (2009). Audit pricing and auditor industry specialization in an emerging market: Evidence from China, Journal of International Accounting, Auditing and Taxation, 18, 60-72.

Watts, R., \& Zimmerman, J. (1983). Agency problems, auditing and the theory of the firm: Some evidence. Journal of Law \& Economics, 26 (3), 613-634.

Watts, R. L., \& Zimmerman, J. L. (1986). Positive accounting theory, Englewood Cliffs, NJ: PrenticeHall.

Whisenant, S., Sankaraguruswamy, S., \& Raghunandan, K. (2003). Evidence on the Joint Determination of Audit and NonAudit Fees. Journal of Accounting Research, 41(4), 721744 .

Willenborg, M. (1999). Empirical analysis of the economic demand for auditing in the initial public offerings market. Journal of Accounting Research, 37(1), 225238.

Zulkarnain, M., \& Shamser, M. (2008). Governance Structure \& External Audit Price: Evidence from an Emerging Economy International Journal of Economics \& Management. 2 (2), 259-279 